\title{
ANALISIS FAKTOR KUNJUNGAN BALITA KE POSYANDU DI KECAMATAN BATANG ANGKOLA KABUPATEN TAPANULI SELATAN
}

\author{
Irwan Batubara, Nurida Nasution, Maslan Dalimunthe \\ Jurusan Prodi Kebidanan Padang Sidempuan \\ Poltekkes Kemenkes Medan
}

\begin{abstract}
Abstrak
Cakupan penimbangan balita di Sumatera Utara masih tergolong rendah, 6 - 11 bulan, 4 kali penimbangan $44,7 \%$, tidak pernah ditimbang 9,8\%, angka tertinggi yang tidak pernah ditimbang pada usia 48-59 bulan . Salah satu bentuk peran serta masyakat terhadap upaya kesehatan adalah keaktifan kunjungan ibu membawa balita ke posyandu untuk memantau pertumbuhan dan perkembangan. Penelitian ini bertujuan untuk menganalisis pengaruh sikap, norma subjektif prilaku kontrol dan jumlah anak, melalui intensi terhadap kunjungan balita ke posyandu. Jenis penelitian ini bersifat survei dengan pendekatan cross sectional. Lokasi penelitian posyandu Huta Tonga, Bintuju, Muara Tais, Sigalangan, Pintu Padang Kecamatan Batang Angkola Kabupaten Tapanuli selatan, Populasi adalah ibu yang mempunyai balita usia 0-36 bulan yang terdaftar dalam catatan Puskesmas Pintu Padang Kecamatan Batang Angkola sebanyak 162 orang. Metode pemilihan sampel proporsional 58 orang dan simple random sampling secara acak untuk masing-masing posyandu. Analisis data menggunakan uji analisis regresi berganda. Hasil analisis juga menunjukkan bahwa tidak ada pengaruh langsung yang signifikan antara sikap, kontrol perilaku, jumlah anak dan intensi terhadap kunjungan ibu ke posyandu, demikian juga pengaruh melalui intensi juga tidak terdapat pengaruh yang signifikan. Perlu dilakukan penelitian lebih lanjut untuk mengetahui faktor lain yang berpengaruh terhadap kunjungan ke posyandu.
\end{abstract}

Kata Kunci : Sikap, Norma Subjektif, Prilaku Kontrol, Intensi ibu Balita

\section{Pendahuluan}

Keadaan status gizi balita di Sumatera Utara berdasarkan berat badan menurut umur pada tahun 2010 menunjukkan berat kurang pada balita juga masih tinggi dibanding angka nasional yaitu mencapai $21,3 \%$ terdiri dari gizi buruk $7,8 \%$ dan gizi kurang $13,5 \%$ dan prevalensi stunting mencapai 41,3\% (Kemenkes RI, 2010). Kondisi status gizi yang buruk pada balita terjadi di berbagai daerah di Sumatera Utara, di Kabupaten Batu Bara terdapat peningkatan persentase kejadian gizi buruk dari 78 di tahun 2008 menjadi 122 pada tahun 2009 (Dinkes Batu Bara, 2010) dan pada tahun 2010 dari 37.906 balita yang ditimbang terdapat 119 gizi kurang dan 29 gizi buruk (Dinkes Provinsi Sumut, 2011).

Cakupan penimbangan balita di posyandu (D/S) merupakan indikator berkaitan cakupan pelayanan gizi pada balita. Berdasarkan hasil Riskesdas 2010 cakupan penimbangan balita secara nasional menunjukkan bahwa anak umur 6-59 bulan yang ditimbang secara rutin (4 kali atau lebih), ditimbang 13 kali dan yang tidak pernah ditimbang berturut-turut sebesar 49,4\%, 26,9\% dan 23,8\% . Cakupan penimbangan balita di Sumatera Utara masih tergolong rendah, 6 - 11 bulan, 4 kali penimbangan $44,7 \%$, tidak pernah ditimbang $9,8 \%$, angka tertinggi yang tidak pernah ditimbang pada usia48-59 bulan 33. Semakin tinggi umur anak semakin tinggi pula persentase anak yang tidak pernah ditimbang dan hal ini mengindikasikan frekuensi kunjungan balita ke posyandu semakin berkurang.

Di Kecamatan Batang Angkola Kabupaten Tapanuli selatan pemanfaatan posyandu sebagai sarana untuk pemantauan tumbuh kembang balita dan pelayanan gizi belum dimanfaatkan secara optimal, mayoritas ibu balita datang ke posyandu untuk mendapatkan imunisasi dan pengobatan. Pada tahun 2015 jumlah posyandu di Puskesmas Pintu Padang Kecamatan Batang Angkola sebanyak 36 posyandu dari seluruh strata, posyandu yang aktif hanya $43 \%$. Jumlah balita 1.210 orang yang ditimbang 54,18\%, sebagian besar tidak hadir secara rutin dan bahkan tidak pernah ikut serta dalam kegiatan posyandu. Capaian cakupan ini masih kurang dari cakupan nasional kunjungan balita ke posyandu yaitu sebesar $90 \%$. Mengetahui pengaruh faktor sikap, norma subjektif dan perceived behavioral control terhadap intensi kunjungan balita ke posyandu di Kecamatan Batang Angkola Kabupaten Tapanuli Selatan 


\section{Metode}

Penelitian ini merupakan jenis penelitian survei dengan pendekatan cross sectional yaitu penelitian yang mempelajari hubungan dan faktor risiko dengan akibat yang berupa penyakit atau keadaan (status) kesehatan tertentu dalam waktu yang bersamaan (Nasir A dkk, 2011). Populasi dalam penelitian ini adalah ibu yang mempunyai balita berusia $0-36$ bulan, berjumlah 112 Ibu balita. Jumlah sampel 58 ibu yang mempunyai anak balita $0-36$ bulan.

Besar sampel tiap Posyandu metode simple random sampling, Posyandu Huta Tonga 12 orang, Bintuju 11 orang, Muara Tais 11 orang, Sigalangan 12 orang, Pintu Padang 12 orang.

\section{Pengumpulan Data}

Data primer dengan wawancara langsung kepada responden menggunakan kuesioner mengacu pada variabel faktor sikap, norma subjektif dan perceived behavioral control terhadap intensi kunjungan balita ke posyandu

Analisis regresi linier berganda adalah hubungan secara linear antara dua atau lebih variabel independen $\left(\mathrm{X}_{1}\right.$, $\mathrm{X}_{2}, \ldots . \mathrm{X}_{\mathrm{n}}$ ) dengan variabel dependen $(\mathrm{Y})$. Analisis ini untuk mengetahui arah hubungan antara variabel independen dengan variabel dependen apakah masingmasing variabel independen berhubungan positif atau negatif. Data yang digunakan berskala interval atau rasio.

\section{Hasil}

Posyandu sasaran adalah Huta Tonga, Bintuju, Muara Tais, Sigalangan, Pintu Padang wilayah kerja Puskesmas Pintu Padang Kecamatan Batang Angkola. Jumlah responden 58 orang, variabel prilaku, norma subjektif, kontrol prilaku, jumlah anak dan intensi atau niat.

Tabel 1. Distribusi Faktor - Faktor yang Mempengaruhi Kunjungan Balita Ke Posyandu

Model Summary

\begin{tabular}{|l|r|r|r|r|}
\hline Model & $\mathrm{R}$ & $\mathrm{R}$ Square & $\begin{array}{c}\text { Adjusted } \\
\text { R Square }\end{array}$ & $\begin{array}{c}\text { Std. Error of } \\
\text { the Estimate }\end{array}$ \\
\hline 1 & $.364^{\mathrm{a}}$ & .132 & .049 & .708 \\
\hline
\end{tabular}

a. Predictors: (Constant), INTENSI (NIAT), KONTROL PERILAKU, NORMA SUBYEKTIF, SIKAP REPONDEN, JUMAH ANAK

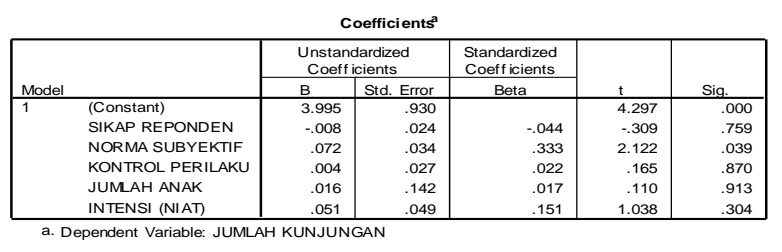

\begin{tabular}{lcc}
\hline \multicolumn{1}{c}{ Variabel } & Frekuensi (n) & Persentase \\
\hline Sikap & 49 & \\
1. Setuju & 9 & 84,5 \\
2. Kurang Setuju & & 15,5 \\
Norma Subyektif & 50 & 86,2 \\
1. Setuju & 8 & 13,8 \\
2. Kurang Setuju & \\
\hline
\end{tabular}

\begin{tabular}{lcc}
\hline Kontrol Perilaku & & \\
1. Setuju & 47 & 81 \\
2. Kurang Setuju & 11 & 19 \\
Intensi & & \\
1. Setuju & 57 & 98.3 \\
2. Kurang Setuju & 1 & 1,7 \\
Jumlah Anak & & \\
1. 1 - 2 Anak & 44 & 75,9 \\
2. Lebih dari 2 Anak & 14 & 24.1 \\
\hline
\end{tabular}

Tabel 1 menunjukkan $84,5 \%$ responden menyatakan setuju berkunjung ke posyandu untuk membawa balitanya guna memantau kesehatan dan tumbuh kembang balitanya. Berdasarkan norma subyektif $86,2 \%$ responden menyatakan setuju. kontrol perilaku $81 \%$ responden menyatakan setuju bahwa dorongan atau motivasi utama berkunjung ke posyandu. Aspek intensi 98,3\% responden menyatakan setuju membawa balitanya ke posyandu setiap bulan.

Tabel 2. Distribusi Kunjungan Balita Ke Posyandu

\begin{tabular}{lcc}
\hline Jumlah Kunjungan & Frekuensi (n) & Persentase $(\%)$ \\
\hline 1. Lebih dari 4 kali & 50 & 86,2 \\
2. Kurang dari 4 kali & 8 & 13,8 \\
\hline
\end{tabular}

Berdasarkan data kunjungan balita ke posyandu yang dikumpulkan sejak bulan April sampai September 2017, diketahui bahwa 86,2\% responden lebih dari 4 kali berkunjung ke posyandu dan $55,17 \%$ responden berkunjung setiap bulan.

\section{Hasil Analisis}

Analisis data penelitian yang bertujuan untuk mengetahui pengaruh sikap reponden, norma subyektif, kontrol perilaku, jumlah anak dan intensi (niat) kunjungan ibu ke posyandu..Hasil analisis menggunakan uji regresi berganda menunjukkan bahwa hanya variable norma subyektif yang berpengaruh terhadap kunjungan ibu ke posyandu dengan nilai signifikan $0,039(<0,05)$, sedangkan besaran nilai rsquare pada uji adalah 0,132 , sehingga dapat dikatakan bahwa kontribusi sikap, norma subyektif, kontrol perilaku, jumlah anak dan intensi terhadap kunjungan ke posyandu adalah $13,2 \%$, sedangkan $86,8 \%$ dipengaruhi oleh factor lain yang tidak termasuk dalam penelitian. Hasil analisis menunjukkan variabel yang mempunyai pengaruh signifikan terhadap kunjungan ibu ke posyandu adalah norma subyektif, dengan nilai signifikansi 0,039 $(<0,05)$, sedangkan koefisien beta untuk variabel norm subyektif sebesar 0,333. Dengan demikian dapat disimpulkan bahwa pengaruh langsung yang diberikan norma obyektif terhadap kunjungan adalah 0,333. Sedangkan pengaruh tidak langsung norma subyektif melalui intensi terhadap kunjungan adalah perkalian antara nilai beta norma subyektif terhadap intensi dengan nilai beta norma subyektif terhadap kunjungan yaitu : 0,294 $\mathrm{x}$ $0,151=0,044$. Maka pengaruh total norma subyektif terhadap kunjungan adalah 0,333 +0,044 =0,377, hal ini berarti bahwa pengaruh langsung norma subyektif terhadap kunjungan lebih besar dibandingkan dengan pengaruh tidak langsung. 
Hasil analisis juga menunjukkan bahwa tidak ada pengaruh langsung yang signifikan antara sikap, kontrol perilaku, jumlah anak dan intensi terhadap kunjungan ibu ke posyandu, demikian juga pengaruh melalui intensi juga tidak terdapat pengaruh yang signifikan.

\section{Pembahasan}

Menurut Green dan Marshall (2005), yang di kutip Notoatmodjo (2003), perilaku dipengaruhi oleh 3 faktor utama yaitu faktor-faktor predisposisi (predisposing factors), faktor-faktor pemungkin (enabling factors) dan faktor-faktor penguat (reinforcing factors). Faktor-faktor predisposisi mencakup pengetahuan dan sikap masyarakat terhadap kesehatan, tradisi dan kepercayaan masyarakat terhadap hal-hal yang berkaitan dengan kesehatan, sistem nilai yang dianut masyarakat, tingkat pendidikan, tingkat sosial ekonomi dan sebagainya. Penelitian ini membahas tentang beberapa faktor yang mempengaruhi ibu-ibu yang mempunyai balita dalam mengujungi posyandu.

Posyandu merupakan program pemerintah, yang memberikan pelayanan kesehatan khusu ibu dan balita. Kegiatan di posyandu seperti meliputi kegiatan pemantauan tumbuh kembang balita, pelayanan kesehatan ibu dan anak seperti : imunisasi untuk pencegahan penyakit, penanggulangan diare, pelayanan $\mathrm{KB}$, penyuluhan dan konseling, rujukan konseling bila diperlukan (Kemenkes RI, 2011a)

Pemerintah sangat mengaharapkan masyarakat cukup aktif ikut dalam kegiatan di posyandu sehingga dapat menekan angka kesakitan pada ibu dan balita, namun demikian tidak semua ibu yang mempunyai balita mau berkunjung ke posyandu secara rutin. Sering sekali para ibu dating ketika ada program dari pemerintah saja seperti bulan vitamin A. Beberapa hal yang berkaitan dengan kunjungan ibu balita ke posyandu diantaranya adalah pengetahuan dan kesadaran ibu tersebut tentang pemanfaatan posyandu bagi tumbuh kembang balitanya, kadang-kadang kepercayaan, tradisi dan sistem nilai masyarakat juga dapat mendorong atau menghambat ibu untuk melakukan kunjungan ke posyandu.

Beberapa hal yang diasumsikan dapat mempengaruhi kunjungan ibu ke posyandu meliputi pendidikan, sikap, norma subyektif dan intensi atau niat. Dalam penelitian ini dilakukan analisis terhadapa factor-faktor tersebut dan diperoleh hasil bahwa norma subyektif mempunyai pengaruh yang signifikan terhadap kunjungan. Sebagian besar ibu-ibu menyampaikan bahwa motivasi mereka untuk berkunjung ke posyandu adalah atas saran dari orangorang terdekat, kondisi ini sangat berhubungan dengan factor kepercayaan, dimana seseorang cenderung lebih mudah percaya pada orang yang sudah dikenal. Norma subjektif diasumsikan dimiliki sebagai suatu fungsi dari beliefs yang secara spesifik seseorang setuju atau tidak setuju untuk menampilkan suatu perilaku. Kepercayaan-kepercayaan yang termasuk dalam norma-norma subjektif disebut juga kepercayaan normatif (normative beliefs). Seorang individu akan berniat menampilkan suatu perilaku tertentu jika ia mempersepsi bahwa orang-orang lain yang penting berfikir bahwa ia seharusnya melakukan hal itu. Orang lain yang penting tersebut bisa suami, orang tua, tokoh masyarakat, kader, petugas kesehatan dan sebagainya.

Sedangkan untuk variable sikap, ternyata dalam penelitian ini tidak mempunyai pengaruh yang signifikans terhadap kunjungan. Hal ini dapat disebabkan karena sebagian besar responden cenderung mempunyai sikap yang positif terhadap kunjungan ke posyandu. Fisbein dan Ajzen (1975) dalam Ismail (2008) memberi pengertian bahwa sikap sebagai faktor predisposisi atau faktor yang ada dalam diri seseorang yang dipelajari untuk memberikan respon dengan cara yang konsisten, yaitu menggambarkan suka atau tidak suka seseorang terhadap suatu objek yang diberikan. Sikap sering diperoleh dari pengalaman sendiri atau orang lain yang paling dekat. Sikap membuat seseorang mendekati atau menjauhi orang lain atau objek lain. Sikap positif terhadap tindakan-tindakan kesehatan tidak selalu terwujud di dalam suatu tindakan tergantung pada situasi saat itu, sikap akan diikuti oleh tindakan mengacu kepada pengalaman orang lain, sikap diikuti atau tidak diikuti oleh suatu tindakan berdasar pada banyak atau sedikitnya pengalaman seseorang.

Responden mayoritas memanfaatkan layanan Posyandu setiap bulan untuk memperoleh informasi kesehatan balitanya, khsusnya pemantauan pertumbuhan. Berdasarkan sikap, kontrol perilaku, jumlah anak dan intensi responden tidak ada pengaruh yang signifikan terhadap kunjungan balita ke posyandu. Penelitian lebih lanjut untuk mengetahui faktor lain yang berpengaruh terhadap kunjungan ke posyandu seperti dukungan keluarga atau pengetahuan ibu tentang layanan yang ada di posyandu.

\section{Daftar Pustaka}

Abdul, A., 2010. Faktor - faktor yang Berhubungan dengan Partisipasi Ibu Balita Untuk Menimbangkan Anaknya ke Posyandu di Desa Penanggalan Kecamatan Penanggalan Kota Subulussalam, Tesis, Program Studi S2 IKM, USU, Medan.

Adisasmito, W., 2007. Sistem Kesehatan. PT. Raja Grafindo Persada. Jakarta

Aisyah, S., 2011. Pengaruh Dukungan Sosial terhadap Partisipasi Ibu Balita dalam Kegiatan Posyandu di Kelurahan Tampan Sekaki Pakanbaru. Tesis. Program Studi S2 IKM. USU, Medan.

Ajzen, I., 1991. The Theory of Planned Behavior. Organizational Behavior and Human Decision Processes, 50, 179-211

Dinas Kesehatan Provinsi Sumatera Utara, 2011. Profil Kesehatan Provinsi Sumatera Utara Tahun 2010. Medan.

Departemen Kesehatan RI, 2006. Pedoman Umum Pengelolaan Posyandu. Jakarta

Departemen Kesehatan RI, 2006. Buku Kader Posyandu dalam Usaha Perbaikan Gizi Keluarga. Jakarta. 
Departemen Kesehatan RI, 2009. Riset Kesehatan Dasar (Riskesdas) Provinsi Sumatera Utara Tahun 2007. Jakarta.

Hartaty, 2006. Hubungan Pengetahuan dan Sikap Ibu Balita dengan Kunjungan ke Posyandu di Kelurahan Bara-Baranya Selatan Wilayah Kerja Puskesmas Bara-Bara Makasar, Indonesian Scientific Journal Database (ISJD), PDII-LIPI, 2(1) : 59-66

Hastuti, SP., 2002. Faktor-Faktor yang Mempengaruhi Ibu Balita Berkunjung ke Posyandu. Badan Penelitian dan Pengembangan Kesehatan. Departemen Kesehatan RI. Jakarta.

Hidayat, A., 2011. Metode Peneltian Kesehatan Paradigma Kuantatif, Health Books, Surabaya.

Kementerian Kesehatan RI, 2010. Riset Kesehatan Dasar (RISKESDAS) 2010, Jakarta. 2011a. Buku Panduan Kader Posyandu Menuju Keluarga Sadar Gizi. Jakarta. 2011b. Pedoman Umum Pengelolaan Posyandu . Jakarta.

Machfoedz, I.2011. Biostatistika. Penerbit Fitramaya, Yogyakarta.

Mar'at. 1984. Sikap, Manusia Perubahan Serta Pengukurannya. Ghalia Indonesia. Bandung:190 hal.

Nasir, A.,Muhith, A., Ideputri, M.E., 2011. Buku Ajar, Metode Penelitian Kesehatan, Konsep Pembuatan Karya Tulis dan Thesis untuk Mahasiswa Kesehatan, Nuha Medika, Yogyakarta.
Notoatmodjo, S., 1993. Pengantar Pendidikan Kesehatan dan Ilmu Perilaku Kesehatan. Andi Offset, Yogyakarta:vi + 152 hal.

2005. Promosi Kesehatan, Teori dan Aplikasi, Rineka Cipta, Jakarta. 2007. Promosi Kesehatan dan Ilmu perilaku. Cetakan I. Rineka Cipta, Jakarta. 2010. Pendidikan dan Perilaku Kesehatan, Rineka Cipta, Jakarta.

Pamungkas, L., 2008. Hubungan antara Faktor Pengetahuan, Sikap dan Kepercayaan dengan Perilaku Ibu Berkunjung ke posyandu III Kelurahan Grabag Kecamatan Grabag Kabupaten Magelang. Tesis. FKM, UI, Jakarta

Raharjo, S., 2003. Hubungan Antara Karakteristik Ibu dan Keaktifan Meningbangkan Anak di Posyandu Desa Jendi Kecamatan Selogiri Kabupaten Wonogiri. Tesis. FKM UNDIP, Semarang.

Ridwan, 2005. Skala Pengukuran Variabel-veriabel Penelitian. Bandung. Penerbit Alfabeta. Jakarta.

Supranto, J., 2010. Analisis Multivariat Arti dan Interpretasi. Penerbit Rineka Cipta. Jakarta

Soetjiningsih, 1998. Tumbuh Kembang Anak. EGC, Jakarta.

Sugiyono, 2009. Metode Penelitian Kuantitatif Kualitatif dan R \& D. Penerbit Alfabeta. Bandung 